\title{
THE EFFECT OF HEALTH PROMOTION WITH BOOKLET AND VIDEO MEDIA ON KNOWLEDGE OF BALANCED NUTRITION IN ADOLESCENT AT SMKN 1 CIKULUR BANTEN \\ Pengaruh Promosi Kesehatan dengan Media Booklet dan Video Terhadap Pengetahuan Gizi Seimbang Pada Remaja di SMKN 1 Cikulur Banten
}

\author{
Nesha Niarvi Chandra ${ }^{1}$, Agustina $^{1}$ \\ ${ }^{1}$ Universitas Pembangunan Nasional Veteran Jakarta \\ neshaniarvic@upnvj.ac.id
}

ARTICLE INFO
Article History:
Received:
September, $23^{\text {th }}, 2020$
Revised:
From March, $18^{\text {th }}, 2021$
Accepted:
July, $14^{\text {th }}, 2021$
Published online
September, $30^{\text {th }}$,
2021

\begin{abstract}
Nutritional health problems nowadays such as consuming less fruits and vegetables, lack of physical activity, and etc. This can be happened due to the lack of knowledge of balanced nutrition possessed by adolescents thus health promotion is needed to increase adolescent knowledge. This research aimed to know the effect of health promotion using booklet and video on knowledge of balanced nutrition in adolescents. The method used in this research was a quasiexperimental design with a non-equivalent control group design. The research was conducted with health promotion using booklet and video media. A sample of 106 people were students of class X SMKN 1 Cikulur Banten which was divided into 53 people in the experimental group and 53 people in the control group. Wilcoxon statistical test results on balanced nutrition knowledge provided with booklet and video obtained a $p$-value of 0,000 . The results of the Mann Whitney statistical test on the knowledge of balanced nutrition obtained a $p$-value of 0,000 . It showed that there is difference in knowledge of balanced nutrition before and after being given health promotion with booklet or video and there is difference in knowledge of balanced nutrition after being given health promotions between booklet and video. Video is more effective than booklet. The more often adolescents receive information about balanced nutrion, both through print and audio-visual media, the knowledge of adolescents about balanced nutrion will increase .
\end{abstract}

Keyword: adolescents, balanced nutrition, booklet, knowledge, video

\begin{abstract}
ABSTRAK
Masalah kesehatan gizi saat ini seperti kurang mengonsumsi buah dan sayur, kurang melakukan aktivitas fisik, dan sebagainya. Hal tersebut dapat terjadi karena kurangnya pengetahuan gizi seimbang yang dimiliki remaja sehingga dibutuhkan promosi kesehatan untuk meningkatkan pengetahuan remaja. Penelitian ini bertujuan untuk mengetahui pengaruh promosi kesehatan menggunakan media booklet dan video terhadap pengetahuan gizi seimbang pada remaja. Metode penelitian ini adalah quasi-experimental dengan rancangan non-equivalent control group design. Penelitian dilakukan dengan promosi kesehatan menggunakan media booklet dan video. Sampel sebanyak 106 orang merupakan siswa kelas X SMKN 1 Cikulur Banten yang dibagi menjadi 53 orang kelompok eksperimen dan 53 orang kelompok kontrol. Hasil uji statistik Wilcoxon pada pengetahuan gizi seimbang yang diberikan dengan media booklet maupun media video diperoleh $p$-value sebesar 0,000 . Hasil uji statistik Mann Whitney pada pengetahuan gizi seimbang diperoleh $p$-value sebesar 0,000. Itu menunjukan bahwa ada perbedaan pengetahuan gizi seimbang sebelum dan sesudah diberikan promosi kesehatan baik menggunakan media booklet maupun video dan ada perbedaan pengetahuan gizi seimbang setelah diberikan promosi kesehatan antara menggunakan media booklet dan media video. Media video lebih efektif dibandingkan dengan media booklet. Semakin sering remaja menerima informasi mengenai gizi seimbang, baik dari media cetak maupun media audio-visual, maka pengetahuan remaja mengenai gizi seimbang akan semakin meningkat.
\end{abstract}

Kata Kunci: booklet, gizi seimbang, pengetahuan, remaja, video 
Nesha, et al. The Effect of Health Promotion with Booklet and Video Media on Knowledge of Balanced Nutrition in Adolescent at SMKN 1 Cikulur Banten

\section{INTRODUCTION}

Adolescence is the transition phase of an individual's life between childhood and adulthood, from 10-19 years old (WHO, 2015). The youth is the future of the nation who plays an important role in achieving the success of Indonesia's development in the future. Hence, it is necessary for the adolescents to be healthy, physically, mentally, and socially.

In achieving a healthy life, good and balanced nutrition is essential to support the growth and development of adolescents. Balanced nutrition is daily food that contains macronutrients and micronutrients in certain quantities that fulfills a person's nutritional needs (Indonesian Ministry of Health, 2014). Nutrient intake can be obtained by consuming a variety of foods, including staple food, side dishes, fruits, and vegetables (Dieny, 2014).

However, the problem is imbalance diet is common among adolescents, unhealthy eating habits such as low consumption of fruit and vegetables, consumption of soft drinks, eating fast food, and skipping breakfast. Based on the 2015 Global School Health Survey (GSHS) result percentage of low consumption of fruit and vegetable was $76.78 \%$, soft drink consumption was $62.34 \%$, fast food consumption was $54.41 \%$, and skipping breakfast was $44.60 \%$ (Indonesian Ministry of Health, 2015).

The nutrients received by the body will be metabolized into potential energy to carry out daily activities. If the intake of nutrients exceeds the required amount, it will produce a generous amount of energy and the excess will be stored inside the body (Qamariyah and Triska, 2018). The excess energy inside the body can be balanced by practicing physical activities that fit what the body needs. Despite this, the current technological advances bring many adolescents to become less physically active. For example, having a gadget has made teenagers lazy since they could access anything with their gadget (Firman and Anung, 2016). Based on 2018 Basic Health Research, as much as $33.5 \%$ of the population aged $\geq 10$ years were physically inactive (Indonesian Ministry of Health, 2018).

Nutrient intake with lack of physical activity can lead to fat deposits and it can also increase body weight as well as obesity (Octaviani et al., 2018). Obesity during adolescence can have long-term consequences
JPH RECODE October 2021; 5 (1): 45-53

http://e-journal.unair.ac.id/JPHRECODE

http://dx.doi.org/10.20473/iphrecode.v5i1.22202

in the future and increase the risk of getting the non-communicable disease (NCD).

Non-communicable disease (NCD) is a disease that is not transmissible from person to person and is a leading cause of nearly $70 \%$ of deaths worldwide (Indonesian Ministry of Health, 2018). Non-communicable diseases, such as hypertension, stroke, cancer, diabetes mellitus, and coronary heart disease, are the most common causes of death. A high incidence of NCD can reduce productivity and life expectancy.

One of the government's efforts to address this health problem is by issuing the Regulation of the Minister of Health of the Republic of Indonesia Number 41 of 2014 on Balanced Nutrition Guidelines. Balanced Nutrition Guidelines are guidelines that consist of balanced nutritional behavior such as eating a variety of foods, clean living behavior, perform adequate physical activity and maintain a normal weight (Indonesian Ministry of Health, 2014).

In order to support the government's effort in developing good dietary habits following Balanced Nutrition Guidelines, it is necessary to increase the adolescents' knowledge about balanced nutrition as there are still many of them who have poor knowledge about Balanced Nutrition Guidelines. Based on a study conducted in Ungaran, it is known that about $26.7 \%$ of adolescents had poor knowledge about Balanced Nutrition Guidelines and $43.3 \%$ of adolescents belonged to the fair level of knowledge category (Winarni et al., 2015). Another research conducted in Gresik showed that as much as $72 \%$ of adolescents had poor knowledge of Balanced Nutrition Guidelines (Agnesia, 2019). Adolescents' knowledge about balanced nutrition can be increased through health promotion.

Health promotion is an activity to increase people's understanding through the dissemination of information that influences the community knowledge, intention, and behavior, both individually and in groups in order to achieve healthy living practice (Maulana and Heri D.J, 2009 in Najahah, 2018)

The use of media in implementing health promotion aims to attract interest and facilitate the target groups to comprehend the information conveyed thus they can learn and adopt positive behaviors obtained from the 
Nesha, et al. The Effect of Health Promotion with Booklet and Video Media on Knowledge of Balanced Nutrition in Adolescent at SMKN 1 Cikulur Banten

health promotion activity (Yulius, 2016). There are several media to support the health promotion activity. The media used in this study were booklet and video since the appearance of these media could be made as attractive as possible that the target groups could easily understand the content of the booklet or the video. The advantage of booklet and video as media is that they can be read or watched anytime and anywhere. The disadvantage of booklet as a media is that it needs a particular place to store hence it is not getting damaged or lost, while the disadvantage of video as a media is that it requires supporting device to play the video, such as mobile phone (Jatmika et al., 2019).

This research was conducted in one of many schools located in Banten Province, SMKN 1 Cikulur Banten. The location selection was based on the result of 2018 Basic Health Research which reported that in Banten, the proportion of the population aged $\geq 3$ years based on the fatty food consumption was $49.5 \%$, sweet food consumption was $61.46 \%$, salty food consumption was $33.1 \%$. The percentage of low consumption of fruit and vegetables among the population aged $\geq 5$ years was $96.9 \%$ and the percentage of low physical activity among the population aged $\geq$ 10 years was $41.2 \%$. The data showed that the diet behavior among people in Banten was not in accordance with the Balanced Nutrition Guidelines.
JPH RECODE October 2021; 5 (1): 45-53

http://e-journal.unair.ac.id/JPHRECODE

http://dx.doi.org/10.20473/iphrecode.v5i1.22202

\section{METHOD}

This was a Quasi-Experimental study with a non-equivalent control group study design. A total of $22410^{\text {th }}$ grade students at SMKN 1 Cikulur Banten were enrolled as the study population, and the sample obtained was 106 students. This research divided two groups of sample into an experimental group that consisted of 53 students and a control group that consisted of 53 students. The researcher gave a booklet as a health promotion media to the experimental group and gave a video to the control group. The research began with a pretest given to both groups, then continued with the information dissemination using a booklet to the experimental group and a video to the control group. The research ended by giving a post-test to both groups. The booklet and video contained information such as the 4 pillars of balanced nutrition, general messages of balanced nutrition, the messages of balanced nutrition for adolescents, and the nutritional need of adolescents. The instruments used in this research were a questionnaire provided through Google Form, a booklet in a form of a PDF, and a video in a form of a Youtube Link. The data collection was carried out using the online method as the research was conducted during the Covid-19 pandemic. This study used two kinds of statistical tests, which were the Wilcoxon Test and the Mann Whitney Test.

\section{RESULT}

Result of Univariate Analysis

Respondents' Characteristics

Table 1 Frequency Distribution of the Experimental Group and Control Group Characteristics

\begin{tabular}{lcccc}
\hline \multirow{2}{*}{ Characterstic } & \multicolumn{2}{c}{ Experimental Group } & \multicolumn{2}{c}{ Control Group } \\
\cline { 2 - 5 } & $\mathbf{n}$ & $\mathbf{\%}$ & $\mathbf{N}$ & $\mathbf{\%}$ \\
\hline Age & 9 & 17.0 & 18 & 34.0 \\
15 & 33 & 62.3 & 27 & 50.9 \\
16 & 11 & 20.8 & 8 & 15.1 \\
17 & & & & \\
Sex & 48 & 90.6 & 11 & 20.8 \\
Male & 5 & 9.4 & 42 & 79.2 \\
Female & 53 & 100 & 53 & 100 \\
\hline Total & & & &
\end{tabular}

The result of the study showed that the majority of the respondents from the experimental control being 16 years $(62.3 \%)$ and were dominated by males $(90.6 \%)$.
Meanwhile, in the control group, more than half of the respondents were aged 16 years $(50.9 \%)$ and were dominated by the female $(79.2 \%)$. 


\section{Respondent's Knowledge about Balanced Nutrition Guidelines Before and After Health Promotion using Booklet and Video}

Table 2 Distribution of Adolescents Level of Knowledge among Experimental Group and Control Group

\begin{tabular}{lcccccccc}
\hline \multirow{2}{*}{$\begin{array}{c}\text { Level of } \\
\text { Knowledge }\end{array}$} & \multicolumn{3}{c}{ Experimental Group } & \multicolumn{3}{c}{ Control Group } \\
\cline { 2 - 9 } & \multicolumn{2}{c}{ Pre-test } & \multicolumn{2}{c}{ Post-test } & \multicolumn{2}{c}{ Pre-test } & \multicolumn{2}{c}{ Post-test } \\
\cline { 2 - 9 } & $\mathbf{n}$ & $\mathbf{\%}$ & $\mathbf{n}$ & $\mathbf{\%}$ & $\mathbf{n}$ & $\boldsymbol{\%}$ & $\mathbf{n}$ & $\mathbf{\%}$ \\
\hline Poor & 51 & 96.2 & 15 & 28.3 & 49 & 92.5 & 1 & 1.9 \\
Fair & 2 & 3.8 & 33 & 62.3 & 4 & 7.5 & 26 & 49.1 \\
Good & 0 & 0 & 5 & 9.4 & 0 & 0 & 26 & 49.1 \\
\hline Total & $\mathbf{5 3}$ & $\mathbf{1 0 0}$ & $\mathbf{5 3}$ & $\mathbf{1 0 0}$ & $\mathbf{5 3}$ & $\mathbf{1 0 0}$ & $\mathbf{5 3}$ & $\mathbf{1 0 0}$ \\
\hline
\end{tabular}

The result of this study reported that nearly all respondents $(96.2 \%)$ had poor knowledge and about $3.8 \%$ of the respondents had fair knowledge. None of the respondents had good knowledge regarding Balanced Nutrition Guidelines before being given health education through a booklet. At the time after health education, there was a significant change in the level of knowledge, the percentage of the respondents with fair knowledge was $62.3 \%$ and $9.4 \%$ of the respondents had good knowledge.
Among the control group, before the health promotion being conducted, a large proportion of the respondents $(92.5 \%)$ had poor knowledge and $7.5 \%$ of the respondents had fair knowledge. None of the respondents had good knowledge regarding Balanced Nutrition Guidelines before being given health education through video. However, after the health promotion being conducted, the percentage of the respondent with a fair level of knowledge increased to $49.1 \%$ and the ones with good knowledge was $49.1 \%$.

Table 3 Distribution of Knowledge Before and After Health Promotion using Booklet and Video

\begin{tabular}{ccccccccc}
\hline Knowledge & \multicolumn{3}{c}{ Experimental Group } & \multicolumn{3}{c}{ Control Group } \\
\cline { 2 - 9 } & Mean & SD & Min & Max & Mean & SD & Min & Max \\
\hline Pre-test & 8.26 & 1.756 & 5 & 12 & 9.85 & 2.239 & 5 & 15 \\
Post-test & 12.43 & 2.005 & 8 & 18 & 15.30 & 2.224 & 11 & 20 \\
\hline
\end{tabular}

The result of the analysis showed that among the experimental, the average pre-test score was 8.26 with a standard deviation of 1.756. Afterward, there was an increase in the average post-test score to 12.43 with a standard deviation of 2.005. In the pre-test, the lowest score was 5 and the highest was 12 . Meanwhile, in the post-test, the lowest and highest score was 8 and 18, respectively.

Among the control group, the average pretest score was 9.85 with a standard deviation of
2.239, and after health promotion being conducted the post-test score increased to 15.30 with a standard deviation of 2.224 . In the pre-test, the lowest score was 5 and the highest was 15 . In the post-test, the lowest score was 11 and the highest 20.

The post-test score was higher among the group that was given the health education using video compared to the group that was given the education using a booklet.

\section{Change of Knowledge of Respondents Before and After Health Promotion using Booklet and Video}

Table 4 Change of Knowledge of Respondents Before and After Health Promotion among Experimental Group and Control Group

\begin{tabular}{lccccc}
\hline \multicolumn{1}{c}{ Group } & Knowledge & n & Mean & SD & \multirow{2}{*}{ P Value } \\
\hline Experimental & Pre-test & & 8.26 & 1.756 & \\
Group & Post-test & & 12.43 & 2.005 & \multirow{2}{*}{0.000} \\
\cline { 1 - 2 } \cline { 5 - 6 } Control Group & Pre-test & & 9.85 & 2.239 & \\
& Post-test & & 15.30 & 2.224 & \\
\hline
\end{tabular}


Nesha, et al. The Effect of Health Promotion with Booklet and Video Media on Knowledge of Balanced Nutrition in Adolescent at SMKN 1 Cikulur Banten
JPH RECODE October 2021; 5 (1): 45-53

http://e-journal.unair.ac.id/JPHRECODE

http://dx.doi.org/10.20473/iphrecode.v5i1.22202
The result of the study obtained that the $p$ value for the experimental group was 0.000 . It was known that the $p$-value $<0.05$ or there was a change in the level of knowledge regarding balanced nutrition at the time after health education using booklet was conducted.
Among the control group, the $p$-value was 0.000 or $p$-value $<0.05$. It indicated that there was a change in the level of education regarding balanced nutrition at the time after health education using video was carried out.

Change of Knowledge of Respondents regarding Balanced Nutrition using Booklet and Video Table 5 Change of Knowledge of Respondents Before and After Health Promotion among Experimental Group and Control Group

\begin{tabular}{ccccc}
\hline \multirow{2}{*}{ Group } & $\mathbf{n}$ & $\begin{array}{c}\text { Mean Rank } \\
\text { (Post-test) }\end{array}$ & Z & P Value \\
\cline { 2 - 5 } & & 36.19 & -5.850 & 0.000 \\
\hline $\begin{array}{c}\text { Booklet } \\
\text { Video }\end{array}$ & 53 & 70.81 & & \\
\hline
\end{tabular}

The Mann-Whitney result showed that the post-test mean rank of the experimental group with health education using booklet was 36.19 , meanwhile the post-test mean rank of the control group with education using video was 70.81 .

It can be concluded that there was a significant change in the level of knowledge between conducted health education using booklet and video. Video as a health promotion media had a greater impact on improving adolescents' knowledge about balanced nutrition compared to the booklet.

\section{DISCUSSION}

Change of Knowledge regarding Balanced Nutrition Before and After Health Promotion using Booklet and Video

Knowledge is the result of the process of not knowing to know as a result of an individual's learning process towards a certain object (Notoatmodjo, 2011). The result of this study showed that among the experimental group, none of whom had a good level of knowledge before the health education was conducted, while the ones with a fair and good level of knowledge were 2 respondents (3.8\%) and 51 respondents $(96.2 \%)$, respectively. After the health promotion using booklet was conducted, as many as 5 respondents $(9.4 \%)$ belonged to the good category, 33 respondents $(62.3 \%)$ belonged to the fair category, and 15 respondents $(28.3 \%)$ belonged to the poor category. It showed that the level of knowledge increased after the health promotion using booklet was carried out. A similar result was also reported in a study conducted in Surakarta by Pratiwi and Dyah in
2017 which stated that the knowledge regarding balanced nutrition among mothers with malnourished children was increased from 53.3\% (poor level of knowledge) to 93.3\% (good level of knowledge) (Pratiwi and Dyah, 2017).

The result of this study showed that among the control group, none of whom had a good level of knowledge before the health education was carried out, while there were 4 respondents $(7.5 \%)$ who had a fair level of knowledge, and the majority of the respondents as many as 49 people $(92.5 \%)$ belonged to poor level of knowledge. After the health promotion using video was conducted, there was a significant change in the level of knowledge. It can be seen from the decline in the percentage of the poor category to $1.9 \%$ or as many as 1 respondent, 26 respondents $(49.1 \%)$ belonged to the fair category. It was indicated that the adolescents' level of knowledge was improving after the health education using video was carried out. This result was in line with a study by Ardie and Sri in 2019 which stated that before the health promotion was conducted, there were $385^{\text {th }}$ grade students at Elementary School 016 Samarinda Seberang who had a good level of knowledge, and after the health promotion being given the number increased to 41 students (85.4\%) (Ardie and Sri, 2019).

Poor level of knowledge among adolescents before the health promotion was conducted was due to the lack of information that they receive both from formal education such as a school where information can be obtained from teachers, and informal education where family and surrounding environment as the 
Nesha, et al. The Effect of Health Promotion with Booklet and Video Media on Knowledge of Balanced Nutrition in Adolescent at SMKN 1 Cikulur Banten

source of information. Other than that, the respondents have yet received any education about balanced nutrition that might cause them to have a low level of knowledge regarding balanced nutrition. This finding was in line with a study by Haris (2018) which stated that the absence of health education was one of the determinant factors of students' low level of knowledge about nutritious food, balanced nutrition, and safe food among students at Elementary School 08 Cilandak Barat (Haris, 2018).

The Wilcoxon test result in this study stated that there was an improvement of the average score after health education using a booklet was carried out. The average pre-test score was 8.26 and there was an improvement on the result of the average post-test score which was 12.43. Another similar finding has also been reported by Lendra et al., which stated that there was an increase in the average score of knowledge among $11^{\text {th }}$ grade students at Senior High School 1 Pontianak at the times before and after the health promotion was conducted (Lendra et al., 2018).

The result of the study showed that there was an improvement in the average score after health education using video was carried out. The average pre-test score was 9.85 and was increased to 15.30 on the average post-test score. A study by Meidiana et al. in 2018 supported the result of this research which reported that there was an improvement in the average score of knowledge from 8.83 to 9.42 after the health promotion using video was carried out among overweight students aged $12-15$ years in Bengkulu.

This study obtained the significance value of 0.000 which indicated that there was a change in the level of knowledge regarding balanced nutrition at the times before and after health education using booklet was conducted as the $p$-value $<0.05$. This finding was similar to a study by Lendra et al. in 2018 which showed that there was a significant change in the knowledge among $11^{\text {th }}$ grade students at Senior High School 1 Pontianak before and after the health education using booklet was conducted (Lendra et al., 2018).

The result of the statistical test using the Wilcoxon test showed that the $p$-value $=0.000$. it was known that there was a change in the level of knowledge regarding balanced nutrition at the times before and after health education using video was carried out as the p-
JPH RECODE October 2021; 5 (1): 45-53

http://e-journal.unair.ac.id/JPHRECODE

http://dx.doi.org/10.20473/iphrecode.v5i1.22202

value < 0.05 . A study by Ardie and Sri in 2019 has a similar result which reported that there was a change in knowledge among $5^{\text {th }}$ grade students at Elementary School 016 Samarinda Seberang after health education using video being given (Ardie and Sri, 2019).

Health promotion as an educational tool aims to improve one's knowledge. In line with a study by Nurdin et al. in 2019 which proved that there was an improvement in knowledge at the times before and after health promotion about balanced nutrition on the student at Junior High School Muhammadiyah Ratatotok Minahasa Regency (Nurdin et al., 2019). Knowledge level improvement can also be determined by several factors such as clear information, method, and good promotional media of conveying the information (Faricha and Chilyatiz, 2014). The objective of using a booklet as a health promotion media is to convey information through pictures and text hence the information becomes familiar among adolescents. This was similar to a study by Lendra et al. which stated that the information received by somebody could increase their knowledge compared to the ones who did not receive any information (Lendra et al., 2018).

Video is a tool or media to convey health messages that aimed to be given to adolescents in hope that there will be a knowledge improvement (Aeni and Diyah, 2018). Using video as a health promotion media aims to convey information through pictures, text, and voice hence the information can be clearly received and easily understood by the adolescents. A study by Aeni and Diyah supported the result of this study which reported that health promotion using video had a greater influence in improving knowledge as video involved sense of hearing and visual hence the message could be conveyed quickly, easily remembered, and could develop the girl students' knowledge at Senior High School 1 Sumber in Cirebon Regency (Aeni and Diyah, 2018).

\section{Change of Knowledge regarding Balanced Nutrition using Booklet and Video}

The result showed that the average score had improved after health education was undertaken using both booklet and video. The adolescents' knowledge improved as they were exposed to information through education (formal, informal, and non-formal). Not only can be obtained from education, but knowledge can also be obtained from any 
Nesha, et al. The Effect of Health Promotion with Booklet and Video Media on Knowledge of Balanced Nutrition in Adolescent at SMKN 1 Cikulur Banten

media, environment, and socio-cultural surroundings (Ningsih, 2018).

Education is a bridge of knowledge. Through education, someone who initially does not acknowledge particular information will be able to discover it. According to Ningsih (2018), education is a process to obtain knowledge, understanding, and ways to act according to what is required Ningsih (2018). Therefore, education in the form of health promotion regarding balanced nutrition is necessary. Hence, there was a knowledge improvement about which among adolescents and can be applied daily.

Health promotion was closely related to the media as a supporting tool in facilitating adolescents in absorbing information. The media must be interesting and contained all the information to be conveyed. According to Arsyad, a piece of information will not be clearly understood if it is only delivered with symbols of words or without anything to support it. The advantage of using media is that it provided adolescents with broader experience in assessing or comprehending information. (Arsyad quoted in Huda, 2016).

This research used two kinds of media, including booklet and video. The efficacy of both media can be seen from the knowledge improvement of adolescents regarding balanced nutrition. From the result of this research, it can be concluded that there was a significant improvement in the knowledge level regarding balanced nutrition after health education using booklet and video were implemented. However, video as a media had a higher impact on improving the adolescents' knowledge about balanced diet compared to the booklet.

A study by Prabandari in 2019 had a similar result that there was a change in the average score of knowledge among adolescents at Vocational High School 2 Muhammadiyal Bantul between before and after the health education using video and booklet were conducted (Prabandari, 2018).

Both media are being able to improve adolescents' knowledge. However, the health promotion using video as a media had a higher average score. Video as a media had more impact on improving knowledge as the learning process using video, adolescents used more sense such as vision and hearing sense that the information was easily remembered. This was in line with the Cone of Experience
JPH RECODE October 2021; 5 (1): 45-53

http://e-journal.unair.ac.id/JPHRECODE

http://dx.doi.org/10.20473/iphrecode.v5i1.22202

Theory by Edgar Dale stated that the learning process through audio-visual media has 50\% retention rates (Audie, 2019).

\section{CONCLUSION}

From the result of this study, it can be concluded that there was an improvement in the level of knowledge regarding balanced nutrition among adolescents after health education using a booklet and a video. Furthermore, there was a change in knowledge level regarding balanced nutrition before and after health education using both booklet and video. In addition, there was also a change in the adolescents' knowledge level about balanced nutrition after being given a booklet and video of health education. Compared to the booklet, video as a medium had greater efficacy in improving adolescents' knowledge about balanced nutrition.

\section{SUGGESTION}

As knowledge level has improved among 10th-grade students at SMKN 1 Cikulur, the students are expected to be more selective in choosing the food and apply a healthy lifestyle following the message in Balanced Nutrition Guidelines for adolescents. The school is expected to pay more attention to the food sold in the school canteen hence the students are being able to consume healthy food at school.

\section{REFERENCES}

Aeni, Nurul dan Diyah Sri Yuhandini. (2018). Pengaruh Pendidikan Kesehatan Dengan Media Video Dan Metode Demonstrasi Terhadap Pengetahuan SADARI. Jurnal Care, 6(2), 162-174.

Agnesia, Dian. (2019). Peran Pendidikan Gizi dalam Meningkatkan Pengetahuan, Sikap dan Perilaku Gizi Seimbang pada Remaja di SMA YASMU Kecamatan Manyar Kabupaten Gresik. Academics in Action Journal, 1(2), 64 - 76.

Ardie, Handri Fadhillah dan Sri Sunarti. (2019). Pengaruh Media Video Terhadap Pengetahuan Dan Sikap Tentang Gizi Seimbang Pada Siswa Kelas V Di SDN 016 Samarinda Seberang. Borneo Student Research

Audie, Nurul. (2019). Peran Media Pembelajaran Meningkatkan Hasil Belajar Peserta Didik. Prosiding Seminar Nasional Pendidikan FKIP, 
Nesha, et al. The Effect of Health Promotion with Booklet and Video Media on Knowledge of Balanced Nutrition in Adolescent at SMKN 1 Cikulur Banten

Universitas Sultan Ageng Tirtayasa, 2(1), 586-595.

Dieny, Fillah Fithra. (2014). Permasalahan Gizi pada Remaja Putri. Yogyakarta: Graha Ilmu.

Faricha, Lailatul dan Chilyatiz Zahroh. (2014). Health Education Mempengaruhi Pengetahuan Siswa SD Kelas IV-V Tentang Makanan Bergizi Seimbang. Jurnal Ilmiah Kesehatan, 7(2), 163-171.

Firman, Salahuddin dan Anung Priambodo. (2016). Hubungan Pemakaian Smartphone Terhadap Aktivitas Olahraga Sehari-Hari Siswa Kelas VII SMP Negeri 1 Trawas. Jurnal Pendidikan Olahraga dan Kesehatan, 4(3), $639-642$.

Haris, Vera Suzana Dewi. (2018). Pengaruh Penyuluhan Dengan Media Animasi Terhadap Pengetahuan Dan Sikap Tentang Makanan Bergizi, Seimbang Dan Aman Bagi Siswa SD 08 Cilandak Barat Jakarta Selatan Tahun 2017. Jurnal Health Quality, 1(1), 38-42.

Huda, Mualimul. (2016). Pembelajaran Berbasis Multimedia Dan Pembelajaran Konvensional (Studi Komparasi di MTs. Al-Muttaqin Plemahan Kediri). Jurnal Penelitian, 10(1), 125-146.

Jatmika, Septian E. D., dkk. (2019). Buku Ajar Pengembangan Media Promosi Kesehatan. Yogyakarta: K-Media.

Kementerian Kesehatan RI. (2014). Peraturan Menteri Kesehatan Republik Indonesia Nomor 41 Tahun 2014 Tentang Pedoman Gizi Seimbang. Jakarta.

Kementerian Kesehatan RI. (2015). Perilaku Berisiko Kesehatan pada PelajarSMP dan SMA di Indonesia (Hasil Survey Nasional Kesehatan Berbasis Sekolah diIndonesia). . Jakarta: Badan Penelitian dan Pengembangan Kesehatan.

Kementerian Kesehatan RI. (2018). Profil Kesehatan Indonesia Tahun 2018. Jakarta: Sekretariat Jenderal Kementerian Kesehatan RI.

Kementerian Kesehatan RI. (2018). Riset Kesehatan Dasar Tahun 2018. Jakarta: Badan Penelitian dan Pengembangan Kesehatan.

Lendra, Minokta, Marlenywati dan Abrori. (2018). Pengaruh Penggunaan Media Booklet Terhadap Peningkatan Pengetahuan Tentang Kecukupan Energi Remaja (Studi Pada Siswa-Siswa Kelas
JPH RECODE October 2021; 5 (1): 45-53

http://e-journal.unair.ac.id/JPHRECODE

http://dx.doi.org/10.20473/iphrecode.v5i1.22202

XI IPS SMA Negeri 1 Pontianak). Jurnal Mahasiswa dan Penelitian Kesehatan.

Meidiana, Risma, Demsa Simbolon dan Anang W. (2018). Pengaruh Edukasi Melalui Media Audio Visual Terhadap Pengetahuan dan Sikap Remaja Overweight', Jurnal Kesehatan, 9(3), 478-484.

Najahah, Imtihanatun. (2018). Pengaruh Penyuluhan Gizi Seimbang pada Remaja Putri terhadap Tingkat Pengetahuan Remaja Putri di Pondok Pesantren Islam NW Penimbung. Media Bina Ilmiah, 12(10), 467 - 474.

Ningsih, Tengku Hartian S. (2018). Pengaruh Edukasi Pedoman Gizi Seimbang Terhadap Pengetahuan dan Sikap Remaja Putri Kurus. Journal of Midwifery Science, 2(2).

Notoatmodjo, Soekidjo. (2011). Kesehatan Masyarakat: Ilmu dan Seni. Jakarta: Rineka Cipta.

Nurdin, Nurhaliza, A.J.M. Ratu, dan Maureen I. Punuh. (2019). Pengaruh Promosi Kesehatan Terhadap Pengetahuan Peserta Didik Tentang Gizi Seimbang Di Smp Muhammadiyah Ratatotok Kabupaten Minahasa Tenggara. Jurnal KESMAS, 8(6), 146 - 153.

Octaviani, Putri, dkk. (2018). Hubungan Pola Makan dan Aktivitas Fisik dengan Status Gizi pada Anak Sekolah Dasar di SD Negeri 47/IV Kota Jambi. Jurnal Kesmas Jambi, 2(2), 56-66.

Prabandari, Agustin Wahyu. (2018). Pengaruh Pemberian Penyuluhan dengan Media Video dan Booklet terhadap Tingkat Pengetahuan Kesehatan Reproduksi Remaja di SMK 2 Muhammadiyah Bantul. Tesis Program Studi Sarjana Terapan, Politeknik Kesehatan Kemenkes Yogyakarta.

Pratiwi, Yessie F. dan Dyah Intan P. (2017). Efektivitas Penggunaan Media Booklet Terhadap Pengetahuan Gizi Seimbang Pada Ibu Balita Gizi Kurang Di Kelurahan Semanggi Kecamatan Pasar Kliwon Kota Surakarta. Jurnal Kesehatan, 10(1), 58 - 68.

Qamariyah, Baiq dan Triska Susila N. (2018). Hubungan Antara Asupan Energi, Zat Gizi Makro dan Total Energy Expenditure dengan Status Gizi Anak 
Nesha, et al. The Effect of Health Promotion with Booklet and Video Media on Knowledge of Balanced Nutrition in Adolescent at SMKN 1 Cikulur Banten

Sekolah Dasar. Amerta Nutrition. Hlm. 59-65.

WHO. (2015). Global Standards For Quality Health-Care Services For Adolescents: A Guide To Implement A StandardsDriven Approach To Improve The Quality Of Health-Care Services For Adolescents, Volume 1: Standards And
JPH RECODE October 2021; 5 (1): 45-53

http://e-journal.unair.ac.id/JPHRECODE

http://dx.doi.org/10.20473/iphrecode.v5i1.22202

Criteria, diakses 17 Juli 2020, https://www.who.int/publications/i/item/ $\underline{9789241549332}$

Yulius, Yosef. (2016). Peranan Desain Komunikasi Visualsebagai Pendukung Media Promosi Kesehatan. Jurnal Seni Desain dan Budaya, 1(2), 42 - 47. 